\title{
Digestibility of amino acids in pig diets containing Eurolysine bacterial protein or Pekilo protein, with spe- cial reference to a gas chromatographic method used in amino acid determination
}

\author{
MATTI NÄSI ${ }^{1}$ AND LEA HUIDA ${ }^{2}$
}

${ }^{1}$ Department of Animal Husbandry, University of Helsinki, 00710 Helsinki 71

${ }^{2}$ Institute of Animal Husbandry, Agricultural Research Centre, 36100 Jokioinen

Abstract. The apparent faecal digestibilities of amino acids were determined in growing pigs on diets in which $50 \%$ or $100 \%$ soybean meal supplement was replaced by Eurolysine bacterial protein or Pekilo protein. The trial was conducted as two $3 \times 3$ Latin squares with six castrated pigs. Compared with the soybean meal supplement, the Eurolysine diet had lower $(\mathrm{P}<0.05)$ digestibilities of arginine, leucine, methionine, phenylalanine and tyrosine. Compared with the Pekilo diet the Eurolysine diet had lower digestibilities $(\mathrm{P}<0.05)$ of alanine, aspartic acid, glutamic acid, glycine, leucine, proline and serine. Lysine digestibility was higher on the Eurolysine diet than on the Pekilo diet.

A gas chromatographic method used in amino acid determination is described and evaluated.

\section{Introduction}

The value of Eyrolysine bacterial protein and Pekilo protein as protein supplements in diets for growing pigs and laying hens was assessed in two experiments (NÄSI 1982, a, b) by replacing conventional protein sources at levels ranging from 0 to $100 \%$. In digestibility trials with growing pigs the diets supplemented with Eurolysine were found to have lower digestibilities than the diets with soybean meal or Pekilo, but combined with barley Eurolysine proved to have a high biological value. Its high lysine content ( 8.3 $\mathrm{g} / 16 \mathrm{~g} \mathrm{~N}$ ) makes it a suitable protein source for growing pigs. In a production trial with laying hens Eurolysine and Pekilo were used to replace soybeanfishmeal supplementation at several different levels. The performance of the hens deteriorated as the replacement level rose. In poultry feeding the sulphur-containing amino acids are of importance, and Eurolysine and Pekilo proved to be deficient in this respect. 
The purpose of this study was to investigate the amino acid digestibilities of the diets containing Eurolysine bacterial protein and Pekilo protein, and to assess the precision of a gas chromatographic method in amino acid determination.

\section{Materials and Methods}

The digestibility trial was carried out with six Landrace pigs weighing $37-65 \mathrm{~kg}$. The total collection method was used and the experiment was designed as two $3 \times 3$ Latin suares, the soybean supplement being replaced with Eurolysine bacterial protein or Pekilo protein at two levels $50 \%$ and $100 \%$. The basic feed was barley milled with a 3-mm sieve. The details of the experimental procedure have been described in a paper by NÄSI (1982 a).

Amino acid analyses were performed on the diet ingredients and faeces, using a Hewlett Packard Model 5710 A gas chromatograph equipped with dual-flame ionisation detectors and a Hewlett Packard Integrator Model $3380 \mathrm{~A}$. The amino acids were determined from their $\mathrm{n}$-heptafluorobutyric (N-HFB) n-propyl ester derivatives, according to the procedure described by MARCH (1975). The columnpacking material, 3 \% SE 30 on Gas Chrom Q 100/120 mesh, was obtained from Applied Science Lab. Glass columns of $3 \mathrm{~m}$ $\times 2 \mathrm{~mm}$ i.d. were used. The columns were conditioned at $250^{\circ} \mathrm{C}$ overnight with a nitrogen flow rate of $30 \mathrm{ml} / \mathrm{min}$.

Feed and faeces samples, $14 \mathrm{mg}$, were hydrolysed in SVL schrew cap tubes $(10 \mathrm{ml})$ with $5 \mathrm{ml}$ of $6 \mathrm{~N} \mathrm{HCl}$ (constant boiling) at $110^{\circ} \mathrm{C}$ for $20 \mathrm{~h}$. The acid to protein ratio was $1000 / 1$. Dry, extra pure nitrogen was bubbled into the mixture $5 \mathrm{~min}$ before the tube was sealed. After hydrolysis $250 \mu \mathrm{l}$ of 3 mmol pipecolic acid solution was added to the hydrolysate and the mixture was filtered through a Whatman GF/A glass microfibre paper. The filtrate was evaporated in a rotary evaporator at $30^{\circ} \mathrm{C}$ and the residue was taken up in $1 \mathrm{ml}$ of $0.1 \mathrm{~N} \mathrm{HCl}$. The solution was cleaned up by passing it through an ionexchange column, $40 \times 5 \mathrm{~mm}$, made of Dowex $50 \mathrm{~W} \times 8,200-400$ mesh. Before the cation-exchange resin was put into the column, it was placed in a

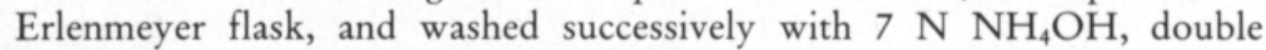
distilled water (to neutral $\mathrm{pH}$ ), $3 \mathrm{~N} \mathrm{HCl}$ and double distilled water (to neutral $\mathrm{pH}$ ). Impurities from the sample were washed out of the column after the sample solution by passing through $4 \mathrm{ml}$ of $0.01 \mathrm{~N} \mathrm{HCl}$ followed by $2 \mathrm{ml}$ of water. Then the amino acid fraction was eluted with $0.5 \mathrm{ml}$ of $2 \mathrm{~N}$ $\mathrm{NH}_{4} \mathrm{OH}$ followed by $4 \mathrm{ml}$ of $7 \mathrm{~N} \mathrm{NH}_{4} \mathrm{OH}$ and $1 \mathrm{ml}$ of water and collected in an evaporation flask $(50 \mathrm{ml})$. The standard amino acid solution was purified daily by ion exchange in the same way. After evaporation in a rotary evaporator under reduced pressure at $30^{\circ} \mathrm{C}$, the n-heptafluorobutyric npropyl esters were derived from the amino acids. Figure 1 shows a gas chromatogram of the n-heptafluorobutyric n-propyl derivatives of 18 amino acids. Each amino acid peak and the pipecolic acid peak represent approximately $0.05 \mu \mathrm{mol}$. Pipecolic acid is used as internal standard. The temperature was raised from $90^{\circ} \mathrm{C}$ to $230^{\circ} \mathrm{C}$ at a rate of $4 \% \mathrm{~min}$; the temperature of the 
Figure 1. Gas chromatogram of the N-HFB n-propyl derivatives of 18 amino acids. Each amino acid peak and the pipecolic peak represents approximately $0.05 \mu \mathrm{mol}$. Pipecolic acid is used as internal standard. The temperature was raised fram $90^{\circ} \mathrm{C}$ to $230^{\circ} \mathrm{C}$ at a rate of $4^{\circ} \mathrm{C} /$ min; the detector and injection block temperature was $250^{\circ} \mathrm{C}$. The flow rate of the carrier $\mathrm{N}_{2}$ was $30 \mathrm{ml} / \mathrm{min}$.

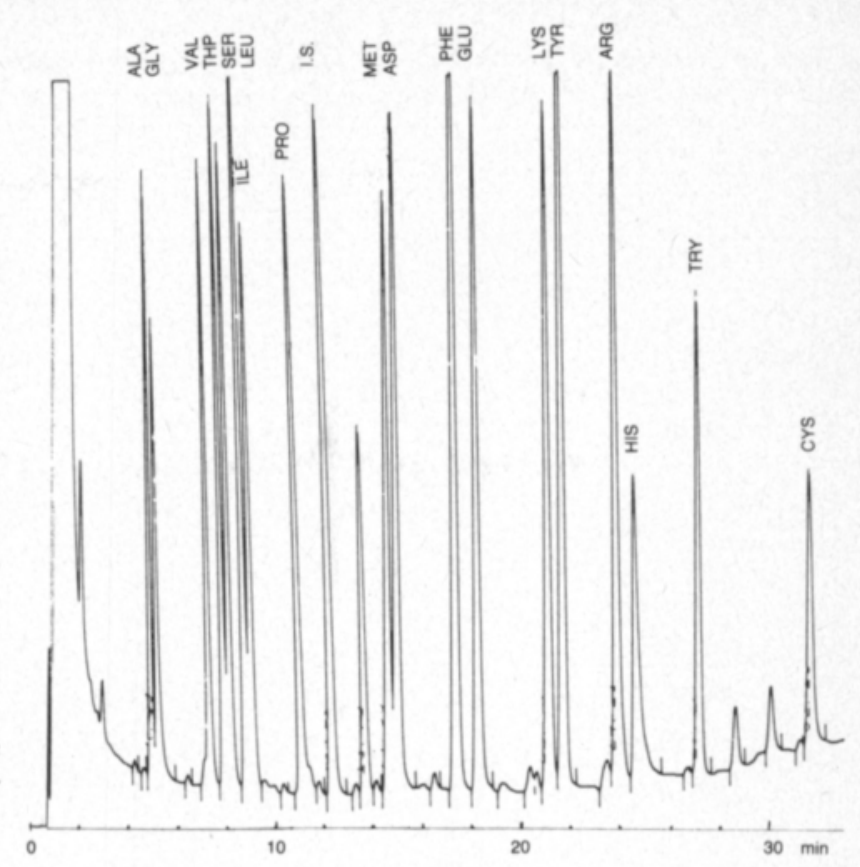

detector and injection block was $250^{\circ}$. The flow rate of the carrier $\mathrm{N}_{2}$ was 30 $\mathrm{ml} / \mathrm{min}$.

The precision of the gas-liquid chromatographic analysis was estimated from five independent analyses performed during one month on a standard amino acid solution and from seven analyses of hydrolysates obtained by repeated hydrolysis of the same wheat sample during a period of three months.

\section{Results and Discussion}

Table 1 shows the precision of the ion-exchange cleanup, derivation and gas-liquid chromatographic analysis obtained with the standard amino acid solution. The mean values of the relative molar response (RMR) with respect to pipecolic acid are calculated from the five analyses. Table 2 presents the mean values and standard deviations of the amounts of amino acids in the seven independent hydrolysates of the same wheat sample. The standard deviations are small and in most cases their relative values are under $5 \%$. The precision of the method can be considered sufficient for practical analytical use. Figure 2 shows the amino acids separated from hydrolysed faecal protein in the form of their N-HFP n-propyl esters.

The amino acid composition of the diet ingredients are shown in Table 3. The lysine content of Eurolysine protein exceeded those of soybean meal and Pekilo by $2-3 \mathrm{~g}$. For pigs, lysine is the essential amino acid that is most limiting in many foods of plant origin, especially cereals. When lysine supplementation is considered for feeds in which lysine is limiting, it is important to obtain an accurate estimate of its availability in these feeds. The 
Table 1. Precision of the ion exchange cleanup, derivation and gas-liquid chromatorgraphic analysis performed on a standard amino acid solution.

\begin{tabular}{llll}
\hline Amino acid & $\begin{array}{l}\text { RMR } \\
\text { mean }\end{array}$ & SD & RSD \% \\
\hline Alanine & 0.63 & 0.02 & 3.3 \\
Argine & 1.31 & 0.03 & 2.1 \\
Aspartic acid & 1.05 & 0.02 & 1.4 \\
Cystine & 1.08 & 0.07 & 6.5 \\
Glutamic acid & 1.10 & 0.03 & 2.6 \\
Glycine & 0.58 & 0.02 & 4.2 \\
Histidine & 0.72 & 0.03 & 3.8 \\
Isoleucine & 0.79 & 0.04 & 5.1 \\
Leucine & 1.01 & 0.01 & 1.3 \\
Lysine & 1.15 & 0.02 & 1.6 \\
Methionine & 0.86 & 0.02 & 1.8 \\
Phenylalanine & 1.40 & 0.04 & 2.5 \\
Proline & 0.93 & 0.02 & 2.3 \\
Serine & 0.91 & 0.04 & 4.5 \\
Threonine & 0.92 & 0.05 & 5.6 \\
Tyrosine & 1.48 & 0.05 & 3.6 \\
Valine & 0.84 & 0.03 & 3.7 \\
\hline
\end{tabular}

Table 2. The mean values and standard deviation of the amounts of amino acids in seven independent hydrolysates of the same wheat sample $(\mathrm{g} / 16 \mathrm{~g} \mathrm{~N})$.

\begin{tabular}{lrrr}
\hline Amino acid & Mean & SD & RSD \% \\
\hline Alanine & 3.6 & 0.14 & 3.9 \\
Arginine & 4.3 & 0.24 & 5.6 \\
Aspartic acid & 4.9 & 0.19 & 3.9 \\
Glutamic acid & 28.6 & 1.07 & 3.7 \\
Glycine & 3.9 & 0.09 & 2.3 \\
Histidine & 2.1 & 0.25 & 11.9 \\
Isoleucine & 3.3 & 0.20 & 6.1 \\
Leucine & 6.6 & 0.20 & 3.0 \\
Lysine & 2.6 & 0.14 & 5.4 \\
Methionine & 1.2 & 0.09 & 7.5 \\
Phenylalanine & 4.9 & 0.24 & 4.9 \\
Proline & 10.4 & 0.33 & 3.2 \\
Serine & 4.5 & 0.13 & 2.9 \\
Threonine & 2.8 & 0.18 & 6.4 \\
Tyrosine & 3.5 & 0.29 & 8.3 \\
Valine & 4.2 & 0.15 & 3.6 \\
\hline
\end{tabular}

content of threonine, the second limiting amino acid in pig diets, was almost the same as in the other protein sources. Methionine was low in both microbial proteins.

Estimates of the average digestibilities of individual amino acids in different diets are presented in Table 4. The apparent digestibilities of 
Figure 2. Amino acid separated from hydrolysed faecal protein in the form of their N-HFB n-propyl esters. The peaks repesent approximately $30 \mu \mathrm{g}$ of faecal protein.

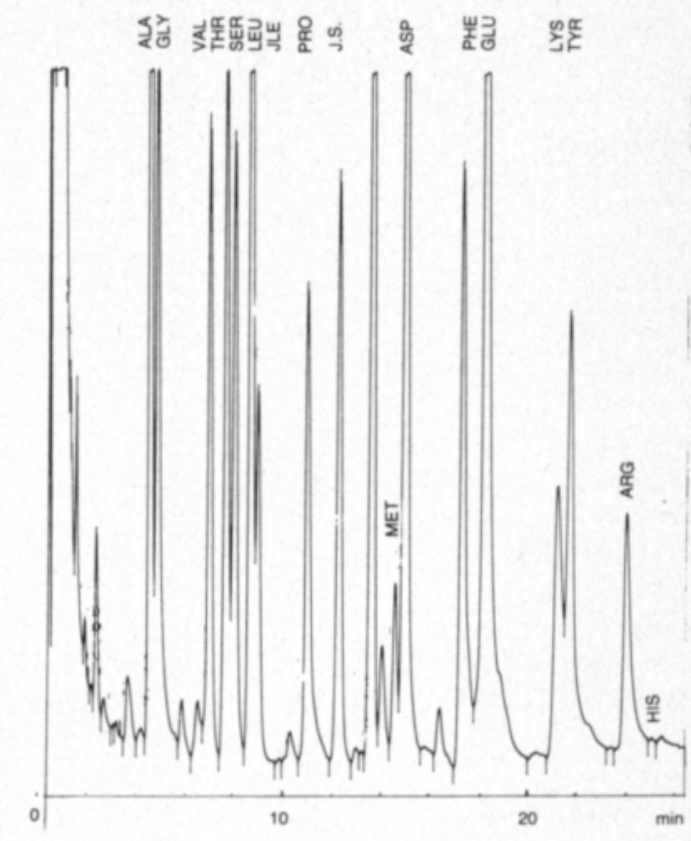

arginine, leucine, methionine, phenylalanine and tyrosine were lower with Eurolysine than with soybean meal supplementation the difference being statistically significant $(P<0.05)$. Compared with the Pekilo diet, the Eurolysine diet had lower digestibilities for alanine, aspartic acid, glutamic acid, glycine, leucine, proline and serine $(\mathrm{P}<0.05)$.

In the Eurolysine diet lysine digestibility was lower $(P>0.05)$ than in the soybean meal diet but higher than in the Pekilo diet.

Table 3. Amino acid composition of the experimental feeds.

\begin{tabular}{lcccc}
\hline $\begin{array}{l}\text { Amino acid } \\
\text { g/16 g N }\end{array}$ & Eurolysine & Pekilo & $\begin{array}{c}\text { Soybean } \\
\text { meal }\end{array}$ & Barley \\
\hline Alanine & 7.0 & 5.6 & 4.4 & 4.1 \\
Arginine & 3.4 & 4.6 & 6.6 & 4.4 \\
Aspartic acid & 7.1 & 7.1 & 11.1 & 5.6 \\
Glutamic acid & 9.7 & 11.5 & 17.4 & 20.2 \\
Glycine & 3.7 & 4.2 & 4.3 & 4.0 \\
Histidine & 0.9 & 1.2 & 2.1 & 2.2 \\
Isoleucine & 3.6 & 3.5 & 5.0 & 3.6 \\
Leucine & 5.8 & 6.1 & 7.7 & 6.7 \\
Lysine & 8.3 & 5.5 & 5.9 & 3.5 \\
Methionine & 0.6 & 0.5 & 1.0 & 1.2 \\
Phenylalanine & 3.0 & 3.3 & 5.0 & 4.6 \\
Proline & 2.6 & 3.5 & 5.1 & 9.4 \\
Serine & 3.0 & 3.7 & 5.3 & 4.1 \\
Threonine & 3.7 & 3.7 & 4.3 & 3.6 \\
Tyrosine & 2.1 & 2.7 & 3.5 & 3.0 \\
Valine & 4.5 & 4.3 & 5.2 & 5.0 \\
\hline
\end{tabular}


Table 4. Apparent digestibilities of amino acids in diets containing soybean meal, Eurolysine or Pekilo as protein supplement.

\begin{tabular}{|c|c|c|c|c|c|}
\hline \multirow[t]{2}{*}{ Amino acid } & \multicolumn{5}{|c|}{ Protein supplement } \\
\hline & $\begin{array}{l}\text { Soybeat meal } \\
100 \%\end{array}$ & $\begin{array}{l}\text { Soybean meal } 50 \% \\
\text { Eurolysine } 50 \%\end{array}$ & $\%$ Eurolysine $100 \%$ & $\begin{array}{l}\text { Eurolysine } 50 \% \\
\text { Pekilo } 50 \%\end{array}$ & Pekilo $100 \%$ \\
\hline Alanine & 73.6 & 74.7 & 66.9 & 69.9 & 74.4 \\
\hline Arginine & $90.7^{a}$ & $87.4^{b}$ & $81.0^{\circ}$ & $79.7^{c}$ & $84.6^{\mathrm{b}}$ \\
\hline Aspartic acid & 82.8 & 76.7 & $71.1^{\mathrm{b}}$ & $72.5^{\mathrm{a}}$ & $72.7^{a}$ \\
\hline Glutamic acid & 89.5 & 86.7 & $82.7^{b}$ & $84.4^{\mathrm{ab}}$ & $85.7^{2}$ \\
\hline Glysine & 78.3 & 76.2 & $69.4^{\mathrm{b}}$ & $73.5^{\mathrm{ab}}$ & $76.1^{2}$ \\
\hline Histidine & 95.5 & 90.5 & 90.2 & 91.8 & 94.7 \\
\hline Isoleucine & 84.8 & 78.2 & 76.9 & 81.0 & 80.1 \\
\hline Leusine & $83.6^{a}$ & $81.0^{\text {ab }}$ & $74.9^{b}$ & $78.4^{a}$ & $79.6^{a}$ \\
\hline Lysine & 82.2 & 81.6 & 77.9 & 74.8 & 74.8 \\
\hline Methionine & $77.8^{\mathrm{a}}$ & $69.6^{a}$ & $56.0^{\mathrm{b}}$ & 57.9 & 60.8 \\
\hline Phenylalanine & $83.2^{2}$ & $79.8^{\mathrm{b}}$ & $74.2^{\mathrm{c}}$ & 76.5 & 77.5 \\
\hline Proline & 89.3 & 88.5 & $84.8^{\mathrm{b}}$ & $85.9^{\mathrm{ab}}$ & $87.2^{2}$ \\
\hline Serine & 85.9 & 81.9 & $77.2^{\mathrm{b}}$ & $79.2^{\mathrm{ab}}$ & $80.7^{2}$ \\
\hline Threonine & 82.2 & 76.9 & 75.3 & 77.2 & 77.3 \\
\hline Tyrosine & $83.5^{\mathrm{a}}$ & $75.1^{\mathrm{b}}$ & $70.0^{c}$ & 72.0 & 73.0 \\
\hline Valine & 83.8 & 78.6 & 76.3 & 80.2 & 80.9 \\
\hline
\end{tabular}

Differences between means with different letters were statistically significant $(a, b, c P<0.05)$.

The digestibilities of various amino acids were lower in diets supplemented with Eurolysine bacterial protein than in diets with soybean meal and Pekilo protein. This is in good agreement with the results for the crude protein digestibilities. In the diets with Eurolysine as protein source the apparent digestibilities were similar to those presented by BRAUDE et al. (1977) for diets containing bacterial protein, but considerably lower than the results of experiments reported by D'MELLO et al. (1976).

The validity of the faecal analysis method for determination of the apparent digestibility of the amino acids is often questioned, partly because secretion of endogenous protein into the digestive tract and partly because of the presence of microorganisms in the hind gut. The microflora of the lower intestine may alter the concentrations of the different amino acids in the faeces (BRAUDE et al. 1977, JUST 1980). However, although possibly modified by microbial activity, the amino acid digestibilities obtained in the present analysis, gave useful information and the results are in good agreement with the data on protein digestibility, nitrogen balance and growth (NÄSI 1982 a). 


\title{
References
}

BRAUDE, R. HOSKING, Z. D., MITCHELl, K. G., PLONKA, S. \& SAMBROOK, I. E. 1977. Pruteen, a new source of protein for growing pigs. I. Metabolic experiment: utilization of nitrogen. Livest. Prod. Sci. 4: 79-89.

D'MELLO, J. P. F., PEERS, D. G. \& WHITTEMORE, C. T. 1976. Utilization of dried microbial cells grown on methanol in a semi-purified diet for growing pigs. Br. J. Nutr. 36: 403-410.

JUST, A. 1980. Ileal digestibility of protein: applied aspects. Current concepts of digestion and absorption in pigs. NIRD-HRI Tech. Bull. no 3: 66-75. Reading.

MARCH, J. F. 1975. A modified technic for the quantitative analysis of amino acids by gas chromatography using n-heptafluorobutyric n-propyl ester derivatives. Anal. Biochem. 69: 420-442.

NÄSI, M. 1982 a. Nutritive value of Eurolysine bacterial protein and Pekilo protein for growing pigs. J. Scient. Agric. Soc. Finl. 54: 263-269.

- 1982 b. Performance of laying hens on diets containing Eurolysine bacterial protein or Pekilo protein. J. Scient Agric. Soc. Finl. 54: 271-278.

Ms received July 19,1982

\section{SELOSTUS}

\section{Eurolysinebakteerivalkuaista ja pekiloproteiinia sisältävien dieet- tien aminohappojen sulavuudet sialla}

\author{
Matti Näsi \\ Helsingin yliopisto, kotieläintieteen laitos 00710 Helsinki 71

\section{Lea Huida} \\ Maatalouden tutkimuskeskus, kotieläinhoidon tutkimuslaitos 36100 Jokioinen
}

Tutkimuksessa määritettiin aminohappojen näennäiset sulavuudet lihasioilla dieeteillä, joissa soijajauho korvattiin $50 \%$ tai $100 \%$ eurolysine bakteeriproteiinilla tai pekiloproteiinilla. Koe tehtiin kuudella leikolla $3 \times 3$ latinalaisen neliön koemallin mukaan. Eurolysineä sisältävällä ruokinnalla oli arginiinin, leusiinin, metioniinin, fenylalaniinin ja tyrosiinin sulavuudet alempia kuin soijaa sisältävällä dieetillä. Samoin alaniinin, asparagiinihapon, glutamiinihapon, glysiinin, leusiinin, proliinin ja seriinin sulavuudet olivat alempia eurolysine- dieetillä verrattuna pekilodieettiin. Lysiinin sulavuus oli eurolysiinidieetillä korkeampi kuin pekilodieetillä.

Tutkimuksessa selvitettiin kaasukromatografisen menetelmän soveltuvuutta rehujen aminohappomäärityksiin. 